\title{
A Mathematical Model of Indirect Solar Drying of Dairy Products (Jameed)
}

\author{
Ghassan M. Tashtosh", Mohammad Jaradat, Shadi Zuraiakt, Mohamad Aljarah \\ Jordan University of Science and Technology, Mechanical Engineering Department, P.O.Box 3030, Irbid, 22110 Jordan \\ *Corresponding Author: gtash@just.edu.jo
}

Copyright $(2014$ Horizon Research Publishing All rights reserved.

\begin{abstract}
A Mathematical modeling of indirect natural convection solar dryer was designed for drying one of the famous dairy product in Jordan called Jameed. The intended solar dryer system is environmentally friendly and consumes zero electricity. The dryer consists of a flat plate solar collector having dimensions of $0.1 \mathrm{~m}$ height, $0.8 \mathrm{~m}$ width and $1.2 \mathrm{~m}$ length. A drying chamber consisting of four trays separated equally from each others at a distance of $0.2 \mathrm{~m}$. The chamber is $1 \mathrm{~m}$ long made of wood. Each tray has a cross section of $0.8 \mathrm{~m} \times 0.4 \mathrm{~m}$. The solar collector is studied separately to establish the effect of changing its width or length on the air outlet temperature and mass flow rate. The drying chamber is used to dry 4 kilograms of jameed, each 1 kilogram is distributed on each tray. The total solar irradiation on the collector surface and chamber walls at each hour of the day was also calculated at the $21^{\text {st }}$ of May in Jordan. At these specific solar irradiation, the flat plate solar collector efficiency was almost constant having an average efficiency of $37 \%$ and a maximum outlet temperature of $41{ }^{\circ} \mathrm{C}$ at $1 \mathrm{p} . \mathrm{m}$. The drying time for trays $1,2,3$ and 4 were $16.4,19.14,22.6$ and 25.71 hours, respectively.
\end{abstract}

Keywords Solar Drying; Dairy Products; Mathematical Model; Moisture Content.

\section{Introduction}

Nearly one-fourth of the world's food supply is lost as a result of microbial spoilage. Due to this, preservation of food and agriculture products is necessary for storing and maintaining their quality for a longer period of time. This can be done in several methods such as refrigeration, heat treatments, radiation, filtration, drying and many other methods. Dehydration is the simplest method of all. Drying generally means removal of relatively small amount of water from material. The water is usually removed as a vapor by air. Microorganisms that cause food spoilage and decay cannot grow and multiply in the absence of water. Also many enzymes that cause chemical changes in food and other biological materials cannot function without water. When the water content is reduced below about $10 \%$ by weight, the microorganism are not active [1]. Drying processes can be categorized according to the physical conditions used to add heat and remove water vapor:

1. In direct drying, heat is added by direct contact with heated air at atmospheric pressure, and the water vapor formed is removed by the air.

2. In vacuum drying, the evaporation of water proceeds more rapidly at low pressures and the heat is added indirectly by contact with a metal wall or by radiation.

3. In freeze drying, water is sublimed from the frozen material.

The potential of using solar energy in the agricultural sector has increased due to fluctuation in the price of fossil fuel, environmental concerns and expected depletion of conventional fossil fuels. Solar assisted drying system is one of the most attractive and promising applications of solar energy systems in Jordan. Solar drying systems are a direct drying technique, where the air is heated using solar radiation to dry food products. Sun drying methods are not new in Jordan, people in rural areas used to dry their products by spreading them on flat surface with or without exposure to the sun in the open air. Direct sun drying requires large open space area, and very much dependent on the availability of sunshine, susceptible to contamination with foreign materials such as dusts, litters and are exposed to birds, insect and rodents. Hence, most agricultural products that are intended to be stored must be dried first. Otherwise insects and fungi, which thrive in moist conditions, render them unusable.

Basically, there are four types of solar air-contact dryers; direct solar dryers, indirect solar dryers, mixed-mode dryers, and hybrid solar dryers. In direct drying, the drying material is subjected to direct sun radiation to be dried, while in indirect drying the air enters a solar collector where it is heated first, and then enters a drying chamber. In mixed mode, air is heated in a collector and flown in to the chamber, in addition to solar radiation subjected on the drying material through the chamber. Hybrid dryers use external unit to heat the air, such as heaters. However, the purpose of this project is to encourage people living in rural areas in Jordan with less financial capabilities to dry their products in a relatively 
low cost system that requires zero electricity benefiting them in accelerating the time for drying, control the final moisture content and reduce wastage through bacterial action.

The simplest of solar cabinet dryer was presented by Othieno [2], it was very simple, and consists essentially of a small wooden hot box. The sides and bottom can be portable and can be constructed from wood or metal sheet. A transparent polyethylene sheet was used as cover at upper surface. Air holes are located on the sides of the drier for circulation. Portable indirect solar dryers also fabricated; made of wood and plywood as reported by Amouzou et al. [3]. The absorber is made galvanized sheet metal painted black. The drying chamber can dry $10-15 \mathrm{~kg}$ of product in 3 days. The wooden frame was not weather-resistant (rain or wind), and the problem of waterproofing arose. Its useful life was 4 years. The multipurpose cement dryer was the same as the brace-type but made from breezeblock instead of wood. It is $4.82 \mathrm{~m} \times 2.82 \mathrm{~m}$ and has load capacity of $80-100 \mathrm{~kg}$. Both the collector for preheating the air and the drying chamber are covered with nine glass panel. To reduce the cost of the absorber, the black metal sheet was replaced with charcoal, a product that is available in rural areas. Bolaji [4] developed and evaluated a solar dryer using a box type absorber collector. The dryer consists of an air heater, an opaque crop bin, and a chimney. The box-type absorber collector made of a glass cover and black absorber plate was inclined at angle of about 20 degree to the horizontal to allow the heated air to rise up the unit with little resistance. He reported that the maximum efficiency obtained in the box-type absorber system was $60.5 \%$ while those of flat plate absorber and fin-type absorber were $21 \%$ and $36 \%$, respectively. He calculated also the maximum average temperature inside the collector and drying chamber were 64 and $57.8^{\circ} \mathrm{C}$, respectively, while the maximum ambient temperature observed was $33.5{ }^{\circ} \mathrm{C}$. Bolaji and Olalusi [5] constructed and evaluated performance of a mixed-mode solar dryer for food preservation. They reported that the temperature rise inside the drying cabinet was up to $74 \%$ at about 3 hours immediately after noon. The drying rate and system efficiency were $0.62 \mathrm{~kg} / \mathrm{h}$ and $57.5 \%$, respectively. The rapid rate of drying in the dryer reveals its ability to dry food items reasonably rapidly to a safe moisture level. Results showed that during the test period revealed that the temperatures inside the dryer and solar collector were much higher than ambient temperature during most hours of the day-light.

Simate [6] designed, constructed and tested two different types of natural convection solar dryers. They reported that, in both configurations, the dryer width is the same as the collector width. Airflow in the dryer is driven by buoyancy pressure created in: (1) the single covered collector with flow over the absorber, (2) the space below the grain bed, (3) the grain bed (4) and the space above the grain bed. For the mixed-mode, the drying chamber cover is transparent whereas for the indirect mode it is opaque. His calculated showed that the optimization gave a shorter collector length for the mixed-mode solar dryer $(1.8 \mathrm{~m})$ than for the indirect-mode dryer $(3.34 \mathrm{~m})$ of the same capacity $(90 \mathrm{~kg})$. The drying cost of the mixed-mode dryer is $12.76 \mathrm{US} \$ /$ tones which was about $26 \%$ lower than that of the indirect-mode; the quantity of dry grain obtained from the mixed-mode for the whole year was about 2.81 tones and was less than that from the indirect mode by $15 \%$.

Madhlopa et al. [7] developed a solar dryer which had composite absorber systems on the principles of psychometric. The dryer consists of a flat plate collector, wire mesh absorber, glass cover, chimney and drying chamber. The drying chamber frames and both the collector were constructed from wooden sheets painted pink. Both the collector was integrated to a drying chamber for food dehydration. Results showed that the temperature rise of drying air was up to $40.8{ }^{\circ} \mathrm{C}$ during noon hours. The thermal efficiency of flat plate collector and wire mesh absorber were approximately $21 \%$ and $17 \%$ respectively at flow rate $0.0083 \mathrm{~kg} \mathrm{~s}^{-1}$.

A mixed-mode wind-ventilated natural convection solar dryer has been reported by Ekechukwe and Norton [8] in their review. The drying system consists essentially of a solar air heater integrated to the drying chamber at the base, and a rotary wind ventilator at the top of the dryer chimney. The warm air outlet of the air heater is connected to the base of drying chamber. To reduce the heat losses, the north-facing wall and bottom horizontal panel are blackened. Addition drying also is achieved from direct solar radiation falling over the product through transparent side, front, and top panels. The rotary wind ventilator was built from moving corrugated vane rotor.

\section{Description of Apparatus}

A mathematical modeling was held for a simple indirect natural convection solar dryer as shown in figure 1 . The dryer consists of a flat plate solar collector attached to a drying chamber made of wood. The collector is $1.2 \mathrm{~m}$ long, $0.1 \mathrm{~m}$ height and $0.8 \mathrm{~m}$ width. The black sheet is made of aluminum of $0.01 \mathrm{~m}$ thickness and the insulation from wood of $0.09 \mathrm{~m}$ thickness. The cover is PMMA transparent plastic with negligible thickness. The drying chamber consists of four trays separated equally from each others at a distance of $0.2 \mathrm{~m}$; each tray is $0.4 \mathrm{~m}$ length and $0.8 \mathrm{~m}$ width.

The basic mechanism of dairy product drying was by heat and moisture transfer between the product material and the air. The heat is transferred to the surface of the material by conduction and convection from adjacent air at temperature above that of the material being dried. If the air is passed through the material at a relative humidity of less than that of moisture content in the material, the air will absorb moisture from the material while increasing its absolute and relative humidity. The drying process was very much close to the evaporative cooling process, in which the air temperature is decreased and its humidity is increased. 


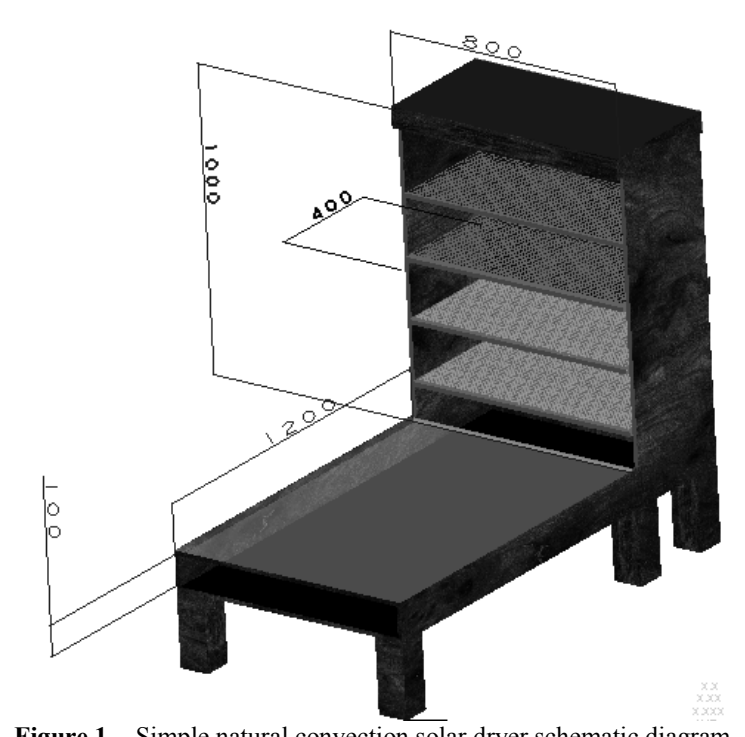

Figure 1. Simple natural convection solar dryer schematic diagram.

\section{Solar Irradiation in Jordan}

Before starting the modeling, it is of various importance to calculate the ambient temperature through the day and the total irradiation from the sun in Jordan. The direction of the sun's rays can be detected if three fundamental equations are known [9 and 10]:

1. Location on the earth's surface.

2. Time of the day.

3. Day of the year.

These three quantities can be described by giving the latitude (L), the hour angle (h), and the sun's declination $(\delta)$, respectively. For Jordan the latitude is equal to $31.95^{\circ}$, the longitude is $35.95^{\circ}$ and the declination angle is taken for the $21^{\text {st }}$ of May to be $20.6^{\circ}$. Equations to determine the hour angle, solar altitude angle $(\lambda)$, angle of incidence between the sun's rays and the normal to the horizontal surface $\left(\Theta_{\mathrm{H}}\right)$ and to the vertical surface $\left(\Theta_{\mathrm{V}}\right)$ are taken from [10]. To calculate the hour angle, local solar time (LST) must be determined using:

$$
\mathrm{LST}=\mathrm{LCT}+\mathrm{EOT}
$$

Where, LCT is the local civil time needed through the day. The hour angle can be determined as:

$$
\mathrm{h}=12-\text { LST }
$$

The equation of time (EOT) also taken at May to be 3.3 minutes [10]. Determining of solar altitude angle $(\lambda)$, angle of incidence between the sun's rays and the normal to the horizontal surface $\left(\Theta_{\mathrm{H}}\right)$ and to the vertical surface $\left(\Theta_{\mathrm{V}}\right)$ is continued using the following equations [10]:

$$
\begin{gathered}
\sin (\lambda)=\cos (\mathrm{L}) * \cos (\mathrm{h}) * \cos (\delta)+\sin (\mathrm{L}) * \sin (\delta) \\
\cos (\Phi)=(\sin (\delta) * \cos (\mathrm{L})-\cos (\delta) * \sin (\mathrm{L}) * \cos (\mathrm{h})) / \cos (\lambda) \\
\mathrm{Y}=\Phi-\Psi
\end{gathered}
$$

The surface azimuth $(\Psi)$ (facing direction) measured clock wise from north and is taken to be $180^{\circ}$.

$$
\cos (\Theta)=\cos (\lambda) * \cos (\mathrm{Y}) * \sin (\xi)+\sin (\lambda) * \cos (\xi)
$$

Where, the tilt angle $(\xi)$ is the angle between the normal to the surface and the normal to the horizontal surface. Hence, a horizontal surface has a tilt angle of zero; a vertical surface has a tilt angle of $90 \mathrm{deg}$. Equation 6 for horizontal and vertical surfaces become:

$$
\begin{gathered}
\cos (\Theta \mathrm{H})=\sin (\lambda) \\
\cos (\Theta \mathrm{V})=\cos (\lambda) * \cos (\mathrm{Y})
\end{gathered}
$$

After determining the angles, the total solar irradiation on the vertical and horizontal surfaces can be calculated using ASHRAE clear sky model [10], starting by calculating the normal direct irradiation $\left(\mathrm{G}_{\mathrm{ND}}\right)$ using the equation:

$$
\mathrm{G}_{\mathrm{ND}}=\mathrm{A} / \exp (\mathrm{B} / \sin (\lambda))
$$

Where $\mathrm{A}$ is the apparent solar irradiation at air mass equal to zero and is found to be $1106 \mathrm{~W} / \mathrm{m}^{2}$. B is the atmospheric extinction coefficient equals to 0.177 and it is a dimensionless number. It should be kept in mind that these values are taken at the $21^{\text {st }}$ of May and the sky is pretty clear (clearness number $=1)$. The direct solar radiation $\left(\mathrm{G}_{\mathrm{DH}}\right)$, diffuse radiation $\left(\mathrm{G}_{\mathrm{dH}}\right)$ and total solar radiation is calculated on a horizontal surface using:

$$
\begin{aligned}
& \mathrm{G}_{\mathrm{dH}}=\mathrm{c}^{*} \mathrm{G}_{\mathrm{ND}} \\
& \mathrm{G}_{\mathrm{DH}}=\mathrm{G}_{\mathrm{ND}} * \cos \left(\Theta_{\mathrm{H}}\right) \\
& \mathrm{G}_{\mathrm{Tot}, \mathrm{H}}=\mathrm{G}_{\mathrm{dH}}+\mathrm{G}_{\mathrm{DH}}
\end{aligned}
$$

For vertical surface,

$$
\begin{array}{r}
\mathrm{GDV}=\mathrm{GND} * \cos (\Theta \mathrm{V}) \\
\mathrm{GRV}=\mathrm{GTotH}{ }^{*} \mathrm{Fwg}{ }^{*} \text { ref }
\end{array}
$$

Reflectivity of the ground is taken to be 0.33 . Configuration or angle factor from vertical surface to ground $\left(\mathrm{F}_{\mathrm{wg}}\right)$ is defined as:

$$
\mathrm{F}_{\mathrm{wg}}=(1-\cos (\xi)) / 2
$$

And is equal 0.5 for vertical surfaces.

If $\cos \left(\Theta_{\mathrm{V}}\right)$ is larger than -0.2 ,

$$
\mathrm{G}_{\mathrm{dV}}=\left(.55+.437 * \cos \left(\Theta_{\mathrm{V}}\right)+.313 *\left(\cos \left(\Theta_{\mathrm{V}}\right)\right)^{\wedge} 2\right)^{*} \mathrm{G}_{\mathrm{dH}}
$$

Otherwise,

$$
\begin{aligned}
& \mathrm{G}_{\mathrm{dV}}=0.45^{*} \mathrm{G}_{\mathrm{dH}} \\
& \mathrm{G}_{\mathrm{Tot}, \mathrm{V}}=\mathrm{G}_{\mathrm{dV}}+\mathrm{G}_{\mathrm{RV}}+\mathrm{G}_{\mathrm{DV}}
\end{aligned}
$$

These equations were solved simultaneously using engineering equation solver software (EES) to obtain the total solar irradiation on the horizontal and vertical surfaces of the solar collector and the drying chamber at each hour of the day. To determine the ambient temperature theoretically, the following equation were used [10]:

$$
\mathrm{T}_{\mathrm{amb}}=\mathrm{T}_{\mathrm{db}}-\mathrm{DR} * \mathrm{X}
$$

Where the design dry bulb temperature $\left(\mathrm{T}_{\mathrm{db}}\right)$ for Jordan is $29.1{ }^{\circ} \mathrm{C}$, the daily range (DR) is $10.2{ }^{\circ} \mathrm{C}$ and the percentage of daily range (X) multiplied by 100 are given in [10]. The 
results were presented and discussed in the discussion part.

\section{Mathematical modeling}

The assumptions for the system as follows:

1. Calculations were based on steady state conditions.

2. Constant specific heat of the air.

3. Air and water vapor was considered to be as an ideal gas.

4. Incompressible flow.

5. Only buoyancy force was responsible for the air flow induced.

6. The total vertical solar irradiation on each surface of the drying chamber is the same.

7. The walls of the drying chamber are considered to emit $20 \%$ of the absorbed solar radiation to the air inside the chamber.

8. The product being dried has a spherical shape.

9. The average relative humidity at May in Jordan stays almost constant through the day and is assumed to be $0.0113 \mathrm{~kg}_{\mathrm{w}} / \mathrm{kg}_{\mathrm{a}}$.

\section{A. Solar Collector}

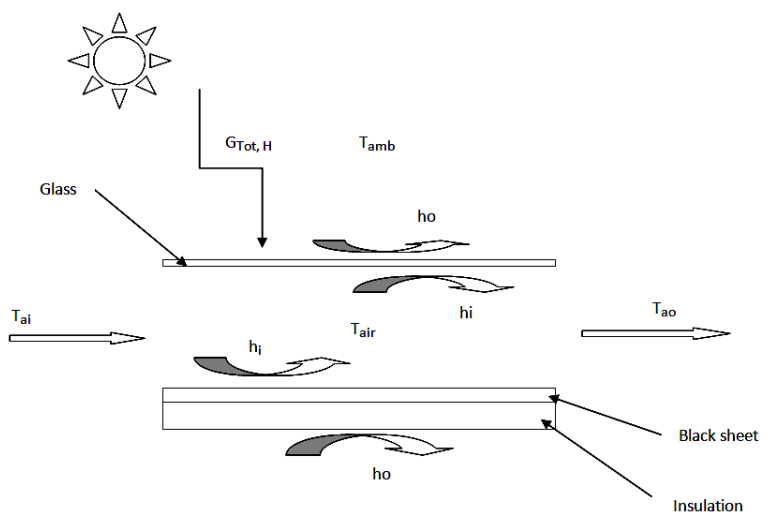

Figure 2. Schematic diagram of the heat transfer modes in the solar collector.

The solar collector model is shown in figure 2. Based on the energy conservation law, a set of equations were constructed along the length of the solar collector. An energy balance on the surface of the glass results in:

$$
\begin{array}{r}
\mathrm{Q}_{\text {solar,H,glass }}+\mathrm{Qr}_{\text {black sheet-glass }}=\mathrm{Q}_{\text {glass-ambient }}+\mathrm{Qr}_{\text {glass-ambient }+} \\
\mathrm{Q}_{\text {glass- ar,in }}(17)
\end{array}
$$

Substituting the heat relations in equation (17),
$\sigma^{*}\left(\left(\mathrm{~T}_{\mathrm{sb}}+273\right)^{4}-\left(\mathrm{T}_{\mathrm{sg}}+273\right)^{4}\right) /\left(1 / \varepsilon_{\mathrm{bs}}-1+1 / \varepsilon_{\mathrm{G}}\right)+\alpha_{\mathrm{G}} * \mathrm{G}_{\mathrm{TotH}}=$ ho* $\left(\mathrm{T}_{\mathrm{sg}}-\mathrm{T}_{\mathrm{amb}}\right)+\varepsilon_{\mathrm{G}}{ }^{* \sigma} *\left(\left(\mathrm{~T}_{\mathrm{sg}}+273\right)^{4}-\left(\mathrm{T}_{\mathrm{amb}}+273\right)^{4}\right)+\mathrm{hi}^{*}\left(\mathrm{~T}_{\mathrm{sg}}\right.$ $\left.-\mathrm{T}_{\mathrm{air}}\right)$

The energy balance equation for the black sheet and insulation is:

$$
\begin{array}{r}
\text { Qsolar,H,black sheet }=\text { Qblack sheet-air, in }+ \text { Qrblack } \\
\text { sheet-glass }+ \text { Qloss to ambient }
\end{array}
$$

Substituting the heat relations in equation (18) results in:

$$
\tau_{\mathrm{G}} * \mathrm{G}_{\mathrm{TotH}} * \alpha_{\mathrm{bs}}=\mathrm{hi} *\left(\mathrm{~T}_{\mathrm{sb}}-\mathrm{T}_{\mathrm{air}}\right)+\sigma^{*}\left(\left(\mathrm{~T}_{\mathrm{sb}}+273\right)^{4}-\left(\mathrm{T}_{\mathrm{sg}}+\right.\right.
$$

$\left.273)^{4}\right) /\left(1 / \varepsilon_{\mathrm{bs}}-1+1 / \varepsilon_{\mathrm{G}}\right)+\left(\mathrm{T}_{\mathrm{sb}}-\mathrm{T}_{\mathrm{amb}}\right) /\left(\mathrm{t}_{\mathrm{bs}} / \mathrm{k}_{\mathrm{bs}}+\mathrm{t}_{\text {ins }} / \mathrm{k}_{\text {ins }}+1 / \mathrm{ho}\right)$

The energy balance equation for the air in the solar collector is:

$$
\mathrm{Q}_{\text {net,air }}=\mathrm{Q}_{\text {black sheet-air,in }}+\mathrm{Q}_{\text {glass- air,in }}
$$

Substituting the heat relations in equation (19) results in:

$$
\mathrm{ma}^{*} \mathrm{Cpa}^{*}\left(\mathrm{~T}_{\mathrm{ao}}-\mathrm{T}_{\mathrm{ai}}\right)=\mathrm{hi}{ }^{*} \mathrm{~b} \mathrm{Lc}^{*}\left(\mathrm{~T}_{\mathrm{sb}}+\mathrm{T}_{\mathrm{sg}}-2 * \mathrm{~T}_{\mathrm{air}}\right)(19 . \mathrm{a})
$$

Temperature of the air inside the collector $\left(T_{\text {air }}\right)$ is assumed to be an average between the inlet and outlet temperature,

$$
\mathrm{T}_{\mathrm{air}}=\left(\mathrm{T}_{\mathrm{ai}}+\mathrm{T}_{\mathrm{ao}}\right) / 2
$$

The internal convection heat transfer coefficient in the collector is taken as $5 \mathrm{~W} / \mathrm{m}^{2} .{ }^{\circ} \mathrm{C}$ as indicated in [10] for plane air spaces. The convection heat transfer coefficient due to the wind is given by [9] as follows:

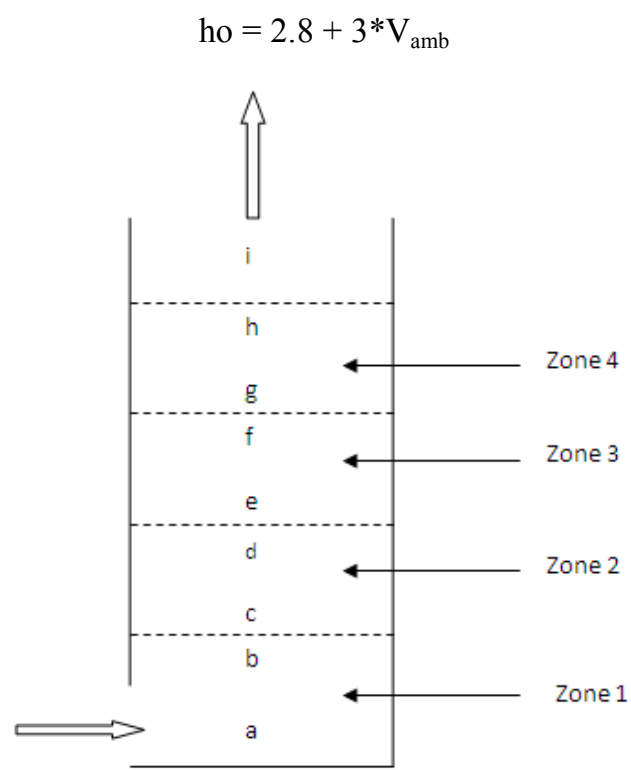

Figure 5. Schematic diagram of the drying chamber 
Table 2. Theoretical results for different absorber length.

\begin{tabular}{|c|c|c|c|c|c|}
\hline $\begin{array}{c}\text { Ambient temperature } \\
\left({ }^{\circ} \mathrm{C}\right)\end{array}$ & $\begin{array}{l}\text { Solar radiation } \\
\qquad\left(\mathrm{W} / \mathrm{m}^{2}\right)\end{array}$ & $\begin{array}{l}\text { Absorber length } \\
\text { (m) }\end{array}$ & $\begin{array}{c}\text { Inlet collector } \\
\text { dimensions (a x } \\
\text { b) }(\mathrm{m} \mathrm{x} \mathrm{m})\end{array}$ & Air flow rate $(\mathrm{kg} / \mathrm{s})$ & Outlet temperature $\left({ }^{\circ} \mathrm{C}\right)$ \\
\hline \multirow{5}{*}{25} & 200 & \multirow{5}{*}{2.0} & \multirow{5}{*}{$0.1 \times 0.8$} & 0.01965 & 30.55 \\
\hline & 400 & & & 0.02473 & 34 \\
\hline & 600 & & & 0.02813 & 36.86 \\
\hline & 800 & & & 0.03073 & 39.38 \\
\hline & 1000 & & & 0.03284 & 41.66 \\
\hline \multirow{5}{*}{25} & 200 & \multirow{5}{*}{3.0} & \multirow{5}{*}{$0.1 \times 0.8$} & 0.02181 & 32 \\
\hline & 400 & & & 0.0275 & 36.45 \\
\hline & 600 & & & 0.03128 & 40.17 \\
\hline & 800 & & & 0.03414 & 43.47 \\
\hline & 1000 & & & 0.03646 & 46.45 \\
\hline \multirow{5}{*}{25} & 200 & \multirow{5}{*}{4.0} & \multirow{5}{*}{$0.1 \times 0.8$} & 0.02336 & 33.2 \\
\hline & 400 & & & 0.02948 & 38.52 \\
\hline & 600 & & & 0.03353 & 43 \\
\hline & 800 & & & 0.03658 & 46.97 \\
\hline & 1000 & & & 0.03904 & 50.58 \\
\hline \multirow{5}{*}{25} & 200 & \multirow{5}{*}{5.0} & \multirow{5}{*}{$0.1 \times 0.8$} & 0.02454 & 34.23 \\
\hline & 400 & & & 0.03101 & 40.33 \\
\hline & 600 & & & 0.03526 & 45.48 \\
\hline & 800 & & & 0.03845 & 50.06 \\
\hline & 1000 & & & 0.041 & 54.25 \\
\hline \multirow{5}{*}{25} & 200 & \multirow{5}{*}{6.0} & \multirow{5}{*}{$0.1 \times 0.8$} & 0.02547 & 35.13 \\
\hline & 400 & & & 0.03222 & 41.94 \\
\hline & 600 & & & 0.03663 & 47.71 \\
\hline & 800 & & & 0.03993 & 52.86 \\
\hline & 1000 & & & 0.04255 & 57.57 \\
\hline
\end{tabular}

Table 3. Theoretical results for different inlet collector dimensions.

\begin{tabular}{|c|c|c|c|c|c|}
\hline \multirow[b]{2}{*}{$\begin{array}{c}\text { Ambient temperature } \\
\left({ }^{\circ} \mathrm{C}\right)\end{array}$} & \multirow[b]{2}{*}{$\begin{array}{l}\text { Solar radiation } \\
\qquad\left(\mathrm{W} / \mathrm{m}^{2}\right)\end{array}$} & \multicolumn{3}{|c|}{ Inlet collector } & \multirow[b]{2}{*}{$\begin{array}{l}\text { Outlet temperature } \\
\qquad\left({ }^{\circ} \mathrm{C}\right)\end{array}$} \\
\hline & & Absorber length (m) & $\begin{array}{c}\text { dimensions } \\
\mathrm{b})(\mathrm{m} \times \mathrm{m})\end{array}$ & Air flow rate (kg/s) & \\
\hline \multirow{7}{*}{25} & \multirow{7}{*}{200} & \multirow{7}{*}{2.0} & $0.1 \times 0.1$ & 0.002437 & 30.58 \\
\hline & & & $0.1 \times 0.2$ & 0.004895 & 30.56 \\
\hline & & & $0.1 \times 0.4$ & 0.009812 & 30.55 \\
\hline & & & $0.1 \times 0.6$ & 0.01473 & 30.55 \\
\hline & & & $0.1 \times 0.8$ & 0.01965 & 30.55 \\
\hline & & & $0.1 \times 1.0$ & 0.02456 & 30.55 \\
\hline & & & $0.1 \times 1.2$ & 0.02948 & 30.55 \\
\hline \multirow{7}{*}{25} & \multirow{7}{*}{400} & \multirow{7}{*}{2.0} & $0.1 \times 0.1$ & 0.003068 & 34.05 \\
\hline & & & $0.1 \times 0.2$ & 0.006163 & 34.02 \\
\hline & & & $0.1 \times 0.4$ & 0.01235 & 34 \\
\hline & & & $0.1 \times 0.6$ & 0.01854 & 34 \\
\hline & & & $0.1 \times 0.8$ & 0.02473 & 34 \\
\hline & & & $0.1 \times 1.0$ & 0.03092 & 33.99 \\
\hline & & & $0.1 \times 1.2$ & 0.03711 & 33.99 \\
\hline \multirow{7}{*}{25} & \multirow{7}{*}{600} & \multirow{7}{*}{2.0} & $0.1 \times 0.1$ & 0.00349 & 36.93 \\
\hline & & & $0.1 \times 0.2$ & 0.007011 & 36.89 \\
\hline & & & $0.1 \times 0.4$ & 0.01405 & 36.87 \\
\hline & & & $0.1 \times 0.6$ & 0.02109 & 36.86 \\
\hline & & & $0.1 \times 0.8$ & 0.02813 & 36.86 \\
\hline & & & $0.1 \times 1.0$ & 0.03518 & 36.86 \\
\hline & & & $0.1 \times 1.2$ & 0.04222 & 36.85 \\
\hline 25 & 800 & 2.0 & $0.1 \times 0.1$ & 0.003812 & 39.47 \\
\hline
\end{tabular}




\begin{tabular}{|c|c|c|c|c|c|}
\hline & & & $0.1 \times 0.2$ & 0.007657 & 39.42 \\
\hline & & & $0.1 \times 0.4$ & 0.01535 & 39.39 \\
\hline & & & $0.1 \times 0.6$ & 0.02304 & 39.38 \\
\hline & & & $0.1 \times 0.8$ & 0.03073 & 39.38 \\
\hline & & & $0.1 \times 1.0$ & 0.03842 & 39.38 \\
\hline & & & $0.1 \times 1.2$ & 0.04611 & 39.37 \\
\hline \multirow{7}{*}{25} & \multirow{7}{*}{1000} & \multirow{7}{*}{2.0} & $0.1 \times 0.1$ & 0.004074 & 41.77 \\
\hline & & & $0.1 \times 0.2$ & 0.008182 & 41.71 \\
\hline & & & $0.1 \times 0.4$ & 0.0164 & 41.67 \\
\hline & & & $0.1 \times 0.6$ & 0.02462 & 41.66 \\
\hline & & & $0.1 \times 0.8$ & 0.03284 & 41.66 \\
\hline & & & $0.1 \times 1.0$ & 0.04105 & 41.66 \\
\hline & & & $0.1 \times 1.2$ & 0.04927 & 41.65 \\
\hline
\end{tabular}

The average velocity of the wind in Jordan at May is taken as $5 \mathrm{~m} / \mathrm{s}$. Solar collector results. Upon solving equations related to solar collector, results were obtained for the outlet temperature and the air flow rate as the length of the collector and the inlet conditions were varied. Table 2 and 3 shows these results.

\section{b. Drying chamber}

The drying chamber consists of four trays and was divided in to four zones as shown in figure 5. Each zone and tray was subjected to the energy conservation law. The energy balance equation for the air in zone 1 is:

$$
\mathrm{ma}^{*} \mathrm{Cpa}^{*}\left(\mathrm{~T}_{\mathrm{b}}-\mathrm{T}_{\mathrm{a}}\right)=20 \% * 2 *(\mathrm{~W}+1) * \mathrm{~s} * \alpha_{\mathrm{wall}} * \mathrm{G}_{\mathrm{Tot}, \mathrm{V}}
$$

The energy balance equation through tray 1 is:

$$
\mathrm{ma} * \mathrm{Cpa} *\left(\mathrm{~T}_{\mathrm{b}}-\mathrm{T}_{\mathrm{c}}\right)=\mathrm{hf}_{1} * \mathrm{~N} * \mathrm{Af} *\left(\mathrm{~T}_{\mathrm{b}}-\mathrm{T}_{\mathrm{sfl}}\right)+\mathrm{m}_{\mathrm{w} 1} * \mathrm{hfg}
$$

The evaporated water flow rate from the drying product is calculated using the mass transfer equation given in [11],

$$
\mathrm{m}_{\mathrm{w} 1}=\mathrm{kg} 1 * A f^{*} \mathrm{~N} *\left(\mathrm{~W}_{\mathrm{wet} 1}-\mathrm{w}_{\mathrm{z} 1}\right)
$$

The mass transfer coefficient for the first tray $(\mathrm{Kg} 1)$ is found using Lewis number (Le). Lewis number for air-water system is equal [12]:

$$
\mathrm{Le}=\mathrm{hf1} /(\mathrm{Cpa} * \mathrm{~kg} 1)=1
$$

The temperature of the surface of the product $\left(\mathrm{T}_{\mathrm{sfl}}\right)$ is equal to the wet bulb temperature of the inlet air since a drying process is taking place on the surface of the product. The driving force for mass transfer is the difference between the concentration of water in the air entering the tray and the moisture content in the food. Hence, the difference between the humidity of the entering air $\left(\mathrm{w}_{\mathrm{z} 1}\right)$ and the humidity of the air film surrounding the food $\left(\mathrm{W}_{\text {wet1 }}\right)$ which is in moisture equilibrium (saturated) at the surface temperature of the food $\left(T_{\text {sfl }}\right)$. Surface temperature of the food is determined from psychometric chart using a built in function in EES that obtains the wet bulb temperature as a function of the total pressure, inlet air temperature and inlet humidity ratio of the air as follows:

$$
\mathrm{T}_{\mathrm{sfl}}=\mathrm{WETBULB}\left(\operatorname{AirH} 2 \mathrm{O}, \mathrm{T}=\mathrm{T}_{\mathrm{b}}, \mathrm{P}=\mathrm{P}, \mathrm{w}=\mathrm{w}_{\mathrm{zl}}\right)
$$

The wet humidity ratio $\left(\mathrm{W}_{\text {wet1 }}\right)$ is calculated using the psychometric relation,

$$
\mathrm{W}_{\text {wet1 }}=0.622 * \mathrm{Ps}_{1} /\left(\mathrm{P}-\mathrm{Ps}_{1}\right)
$$

Saturated pressure $\left(\mathrm{P}_{\mathrm{s} 1}\right)$ is calculated by also using a built in function in EES as follows:

$$
\mathrm{Ps}_{1}=\mathrm{P} \_ \text {SAT }\left(\text { Water, } \mathrm{T}=\mathrm{T}_{\text {sfl }}\right. \text { ) }
$$

A mass balance equation for the air going through tray 1 allows the determination of the humidity ratio of the air leaving the tray. The mass balance equation is:

$$
\mathrm{w}_{\mathrm{z} 2}=\mathrm{m}_{\mathrm{w} 1} / \mathrm{ma}+\mathrm{w}_{\mathrm{z} 1}
$$

The convection heat transfer coefficient for the surface of the product (hfl) is determined using the correlation due to Churchill for spheres [10],

$$
\begin{array}{r}
\mathrm{Nu}_{\mathrm{D}}=\mathrm{hf}_{1} * \mathrm{D} / \mathrm{K}_{\mathrm{film} 1}=0.589 * \mathrm{Ra}_{\mathrm{D} 1}{ }^{(1 / 4)} /\left(1+(0.469 / \mathrm{Pr})^{(9 / 16)}\right)^{(4 / 9)} \\
+2(30)
\end{array}
$$

Equation (30) is satisfied for Prandtl number $\operatorname{Pr} \geq 0.7$ and for $\mathrm{Ra}_{\mathrm{D}} \leq 10^{11}$. Rayleigh number is calculated using:

$$
\begin{gathered}
\mathrm{Ra}_{\mathrm{D} 1}=\mathrm{g} * \beta_{\text {film1 }} *\left(\mathrm{~T}_{\mathrm{b}}-\mathrm{T}_{\mathrm{sfl}}\right) * \mathrm{D}^{3} /\left(v_{\text {film } 1} * \operatorname{diff}_{\text {film1 }}\right) \\
\beta_{\text {film1 }}=1 /\left(\mathrm{T}_{\text {film1 }}+273\right) \\
\operatorname{diff}_{\text {film1 }}=\mathrm{k}_{\mathrm{film} 1} /\left(\rho_{\text {film } 1} * \mathrm{Cpa}\right)
\end{gathered}
$$

Formulas used to calculate the fluid physical properties at any temperature are given by empiric correlations fitted using air tables and water tables these properties are:

$$
\begin{aligned}
& \mathrm{h}_{\mathrm{fg} 1}=\left(\left(6254828.56-11742.338 * \mathrm{~T}_{\mathrm{b}}+6.337 * \mathrm{~T}_{\mathrm{b}}{ }^{2}-\right.\right. \\
& \left.\left.0.049241 * \mathrm{~T}_{\mathrm{b}}{ }^{3}\right)^{0.5}\right) * 1000 \\
& \mathrm{~K}_{\mathrm{film} 1}=1.52 * 10^{-4}+4.42 * 10^{-5} *\left(\mathrm{~T}_{\text {film } 1}+273\right)+8 * 10^{-9} *\left(\mathrm{~T}_{\mathrm{film} 1}+\right. \\
& 273)^{2} \\
& v_{\text {film1 }}=-1.1555^{*} 10^{-14} *\left(\mathrm{~T}_{\text {film } 1}+273\right)^{3}+9.5728 * 10^{-11} *\left(\mathrm{~T}_{\text {film } 1}+\right. \\
& 273)^{2}+3.7604 * 10^{-8 *}\left(\mathrm{~T}_{\text {film } 1}+273\right)-3.4484 * 10^{-6}(36) \\
& \rho_{\text {film } 1}=360.77819 *\left(\mathrm{~T}_{\text {film } 1}+273\right)^{-1.00336} \\
& \mathrm{~T}_{\text {film1 }}=\left(\mathrm{T}_{\mathrm{b}}+\mathrm{T}_{\text {sfl }}\right) / 2
\end{aligned}
$$

Prandtl number was assumed to be constant for the air and equals 0.7 since the operating temperature range in the system will result in negligible change in the Prandtl number. Upon going through the three other trays and zones the equations stays the same, while the temperature, humidity ratio, mass flow rate of the air and drying rate is changed 
from zone to zone. These equations are summarized as follows:

Zone 2:

$$
\mathrm{ma}^{*} \mathrm{Cpa} *\left(\mathrm{~T}_{\mathrm{d}}-\mathrm{T}_{\mathrm{c}}\right)=0.2 * 2 *(\mathrm{~W}+1) * \mathrm{~s} * \alpha_{\mathrm{wall}} * \mathrm{G}_{\mathrm{Tot}, \mathrm{V}}
$$

Tray 2:

$$
\begin{gathered}
\mathrm{ma}^{*}{ }^{\mathrm{Cpa}}\left(\mathrm{T}_{\mathrm{d}}-\mathrm{T}_{\mathrm{e}}\right)=\mathrm{hf}_{2} * \mathrm{~N} * \mathrm{Af}^{*}\left(\mathrm{~T}_{\mathrm{d}}-\mathrm{T}_{\mathrm{sf} 2}\right)+\mathrm{m}_{\mathrm{w} 2} * \mathrm{hfg}_{2}(40) \\
\mathrm{T}_{\mathrm{sf} 2}=\mathrm{WETBULB}\left(\mathrm{AirH} 2 \mathrm{O}, \mathrm{T}=\mathrm{T}_{\mathrm{d}}, \mathrm{P}=\mathrm{P}, \mathrm{w}=\mathrm{w}_{\mathrm{zz} 2}\right) \\
\mathrm{m}_{\mathrm{w} 2}=\mathrm{kg} 2 * \mathrm{Af} * \mathrm{~N} *\left(\mathrm{~W}_{\mathrm{wet} 2}-\mathrm{w}_{\mathrm{z} 2}\right) \\
\mathrm{Kg} 2=\mathrm{hf}_{2} / \mathrm{Cpa}
\end{gathered}
$$

Zone 3:

$$
\mathrm{ma}^{*} \mathrm{Cpa} *\left(\mathrm{~T}_{\mathrm{f}}-\mathrm{T}_{\mathrm{e}}\right)=0.2 * 2 *(\mathrm{~W}+1) * \mathrm{~s}^{*} \alpha_{\mathrm{wall}} * \mathrm{G}_{\mathrm{Tot}, \mathrm{V}}
$$

Tray 3:

$$
\begin{gathered}
\mathrm{ma}^{*} \mathrm{Cpa}^{*}\left(\mathrm{~T}_{\mathrm{f}}-\mathrm{T}_{\mathrm{g}}\right)=\mathrm{hf}_{3} * \mathrm{~N} * \mathrm{Af} *\left(\mathrm{~T}_{\mathrm{f}}-\mathrm{T}_{\mathrm{sf} 3}\right)+\mathrm{m}_{\mathrm{w} 3} * \mathrm{hfg}_{3} \\
\mathrm{~T}_{\mathrm{sf3}}=\mathrm{WETBULB}\left(\mathrm{AirH} 2 \mathrm{O}, \mathrm{T}=\mathrm{T}_{\mathrm{f}}, \mathrm{P}=\mathrm{P}, \mathrm{w}=\mathrm{W}_{\mathrm{z} 3}\right) \\
\mathrm{m}_{\mathrm{w} 3}=\mathrm{kg} 3 * \mathrm{Af} * \mathrm{~N} *\left(\mathrm{~W}_{\mathrm{wet3} 3}-\mathrm{w}_{\mathrm{z} 3}\right) \\
\mathrm{Kg} 3=\mathrm{hf}_{3} / \mathrm{Cpa}
\end{gathered}
$$

$$
\begin{gathered}
273)^{2}+3.7604 * 10^{-8 *}\left(\mathrm{~T}_{\text {film } 3}+273\right)-3.4484 * 10^{-6} \\
\rho_{\text {film } 3}=360.77819 *\left(\mathrm{~T}_{\text {film } 3}+273\right)^{-1.00336} \\
\mathrm{~T}_{\text {film } 3}=\left(\mathrm{T}_{\mathrm{f}}+\mathrm{T}_{\mathrm{sf} 3}\right) / 2
\end{gathered}
$$

Zone 4:

$$
\mathrm{ma}^{*} \mathrm{Cpa}^{*}\left(\mathrm{~T}_{\mathrm{h}}-\mathrm{T}_{\mathrm{g}}\right)=0.2 * 2 *(\mathrm{~W}+1) * \mathrm{~s}^{*} \alpha_{\mathrm{wall}} * \mathrm{G}_{\mathrm{Tot}, \mathrm{V}}
$$

Tray 4 :

$$
\begin{aligned}
& \mathrm{ma}^{*} \mathrm{Cpa}^{*}\left(\mathrm{~T}_{\mathrm{h}}-\mathrm{T}_{\mathrm{i}}\right)=\mathrm{hf}_{4} * \mathrm{~N} * A f^{*}\left(\mathrm{~T}_{\mathrm{h}}-\mathrm{T}_{\mathrm{sf} 4}\right)+\mathrm{m}_{\mathrm{w} 4} * \mathrm{hfg}_{4}(74) \\
& \left.\mathrm{T}_{\mathrm{s} 4 \mathrm{f}}=\text { WETBULB(AirH2O, } \mathrm{T}=\mathrm{T}_{\mathrm{h}}, \mathrm{P}=\mathrm{P}, \mathrm{w}=\mathrm{w}_{\mathrm{z} 4}\right)(75) \\
& \mathrm{m}_{\mathrm{w} 4}=\mathrm{kg} 4 * \mathrm{Af}^{*} \mathrm{~N} *\left(\mathrm{~W}_{\mathrm{wet} 4}-\mathrm{w}_{\mathrm{z} 4} \quad\right)(76) \\
& \mathrm{Kg} 4=\mathrm{hf}_{4} / \mathrm{Cpa} \\
& \mathrm{W}_{\text {wet4 }}=0.622 * \mathrm{Ps}_{4} /\left(\mathrm{P}-\mathrm{Ps}_{4}\right) \\
& \mathrm{Ps}_{4}=\mathrm{P}_{-} \mathrm{SAT}\left(\text { Water, } \mathrm{T}=\mathrm{T}_{\mathrm{sf} 4}\right) \\
& \mathrm{w}_{\mathrm{z} 5}=\mathrm{m}_{\mathrm{w} 4} / \mathrm{ma}+\mathrm{w}_{\mathrm{z} 4} \\
& \mathrm{hf}_{4}=\left(0.589 * \mathrm{Ra}_{\mathrm{D} 4}{ }^{(1 / 4)} /\left(1+(0.469 / \mathrm{Pr})^{(9 / 16)}\right)^{(4 / 9)}+2\right) *\left(\mathrm{k}_{\mathrm{film} 4} / \mathrm{D}\right) \\
& \mathrm{Ra}_{\mathrm{D} 4}=\mathrm{g} * \beta_{\text {film4 }} *\left(\mathrm{~T}_{\mathrm{h}}-\mathrm{T}_{\mathrm{sf} 4}\right) * \mathrm{D}^{3} /\left(v_{\text {film } 4} * \operatorname{diff}_{\text {film4 }}\right) \\
& B_{\text {film } 4}=1 /\left(T_{\text {film } 4}+273\right) \\
& \operatorname{diff}_{\text {film } 4}=\mathrm{k}_{\text {film } 4} /\left(\rho_{\text {film } 4} * \text { ppa }\right) \\
& \mathrm{h}_{\mathrm{fg} 4}=\left(6254828.56-11742.338 * \mathrm{~T}_{\mathrm{h}}+6.337 * \mathrm{~T}_{\mathrm{h}}{ }^{2}-\right. \\
& \left.0.049241 * \mathrm{~T}_{\mathrm{h}}{ }^{3}\right)^{0.5 * 1000}(85) \\
& \mathrm{k}_{\text {film } 4}=1.52 * 10^{-4}+4.42 * 10^{-5} *\left(\mathrm{~T}_{\text {film } 4}+273\right)+8 * 10^{-9} *\left(\mathrm{~T}_{\text {film } 4}+\right. \\
& 273)^{2} \\
& v_{\text {film } 4}=-1.1555^{*} 10^{-14} *\left(\mathrm{~T}_{\text {film } 4}+273\right)^{3}+9.5728 * 10^{-11} *\left(\mathrm{~T}_{\text {film } 4}+\right. \\
& 273)^{2}+3.7604 * 10^{-8 *}\left(\mathrm{~T}_{\text {film } 4}+273\right)-3.4484 * 10^{-6}(87) \\
& \rho_{\text {film } 4}=360.77819 *\left(T_{\text {film } 4}+273\right)^{-1.00336}(89) \\
& \mathrm{T}_{\mathrm{film} 4}=\left(\mathrm{T}_{\mathrm{h}}+\mathrm{T}_{\mathrm{sf} 4}\right) / 2
\end{aligned}
$$

To determine the time needed for drying at constant heat supply from the sun based on steady state assumption, the moisture content based on wet basis of the product has to be known. In this experiment the product used to be dried was Jameed. Jameed is very popular in Jordan because it is used in making the national dish, Mansaf. Jameed is hard dry yoghurt made from sheep's milk. Milk is kept in a fine woven cheese cloth to make a thick yogurt. Salt is added daily to thicken the yogurt even more and the outside of the yogurt filled cheesecloth is rinsed with water to allow any remaining whey to seep through. After a few days of salting the yogurt, it becomes very dense and it can be removed from the cheesecloth and shaped into round balls. It is then set to dry for a few days, if it's dried in the sun it becomes yellow and if it's dried in the shade it remains white, it is important that the Jameed is dry to the core because any dampness can spoil the preservation process. However, before Jameed has been dry it contains about $75 \%$ water of its weight and it is preferred to be dried to about $10 \%$ by weight wet basis.

Knowing the initial and final moisture content of Jameed, its initial mass and the drying rate, one can calculate the time needed for drying using: 


$$
\begin{aligned}
& \mathrm{m}_{\mathrm{w} 1}=\mathrm{M}_{\mathrm{w} 1} / \mathrm{DT}_{1} \\
& \mathrm{~m}_{\mathrm{w} 2}=\mathrm{M}_{\mathrm{w} 2} / \mathrm{DT}_{2} \\
& \mathrm{~m}_{\mathrm{w} 3}=\mathrm{M}_{\mathrm{w} 3} / \mathrm{DT}_{3} \\
& \mathrm{~m}_{\mathrm{w} 4}=\mathrm{M}_{\mathrm{w} 4} / \mathrm{DT}_{4}
\end{aligned}
$$

The mass of the initial water content in the product $\left(\mathrm{M}_{\mathrm{w}}\right)$ at each tray depends on the mass of the product at each tray (Mf) and is calculated by:

$$
\begin{gathered}
\mathrm{M}_{\mathrm{w} 1}=\left(\left(\mathrm{z}_{\mathrm{i}}-\mathrm{z}_{\mathrm{f}}\right) /\left(1-\mathrm{z}_{\mathrm{f}}\right)\right) * \mathrm{M}_{\mathrm{F} 1} \\
\mathrm{M}_{\mathrm{w} 2}=\left(\left(\mathrm{z}_{\mathrm{i}}-\mathrm{z}_{\mathrm{f}}\right) /\left(1-\mathrm{z}_{\mathrm{f}}\right)\right) * \mathrm{M}_{\mathrm{F} 4} \\
\mathrm{M}_{\mathrm{w} 3}=\left(\left(\mathrm{z}_{\mathrm{i}}-\mathrm{z}_{\mathrm{f}}\right) /\left(1-\mathrm{z}_{\mathrm{f}}\right)\right) * \mathrm{M}_{\mathrm{F} 3} \\
\mathrm{M}_{\mathrm{w} 4}=\left(\left(\mathrm{z}_{\mathrm{i}}-\mathrm{z}_{\mathrm{f}}\right) /\left(1-\mathrm{z}_{\mathrm{f}}\right)\right) * \mathrm{M}_{\mathrm{F} 4}
\end{gathered}
$$

The initial mass for each tray was taken to be $1 \mathrm{~kg}$.

[1] Figure 3 shows the total irradiation on the solar collector and the walls of the drying chamber versus time. The peaks can be clearly seen at $1 \mathrm{p} . \mathrm{m}$.

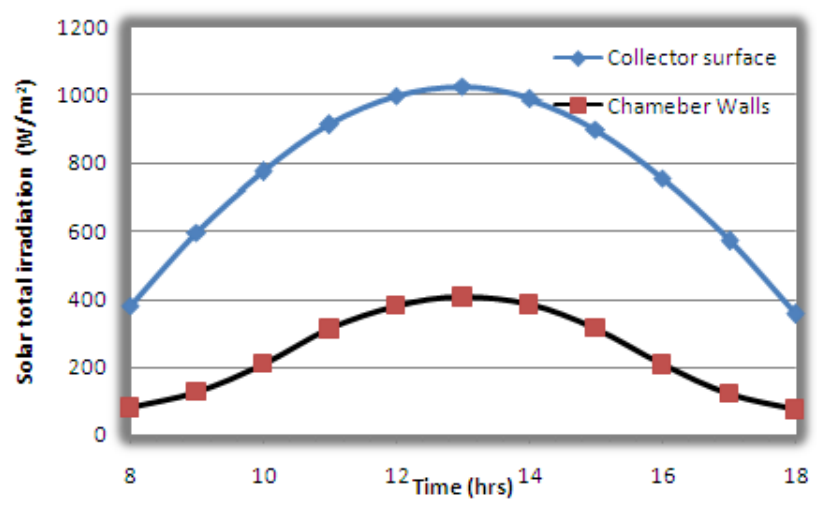

Figure 3. Total Solar Irradiation.

\section{a . Fluid flow}

As the collector absorbed heat from the sun, the air above the black sheet is heated due to convection. The density of the heated air will decrease. Hence, the drying chamber will act as a vertical chimney, where the ambient air that has a higher density will replace the hot air. As a result a buoyancy force acts to produce a draft that will suck air from the collector depending on the temperature the heated air will reach and the pressure drop due to friction and trays as the air leaves the chamber.

A mathematical modeling based on Bernoulli's equation is used to estimate the system flow rate. Since the total pressure in the system is an atmospheric pressure, and the density change of the air is very small, Boussinesq approximation states that density differences are sufficiently small to be neglected, except where they appear in terms multiplied by the acceleration due to gravity $(\mathrm{g})$. The Bernoulli equation will reduce to:

$$
\text { Draft }=g *\left(\rho_{\mathrm{amb}}-\rho_{\mathrm{ao}}\right) * \mathrm{Lch}=\mathrm{f}^{*}\left(\mathrm{Le} / \mathrm{D}_{\mathrm{h}}\right) *\left(\rho_{\mathrm{ao}} * \mathrm{~V}^{2} / 2\right)
$$

In equation (99) the first term is the draft caused by the drying chamber and the second one is the pressure drop due to trays and total length.

Equation (99) becomes,

$$
\begin{array}{r}
\mathrm{g} *\left(\rho_{\mathrm{amb}}-\rho_{\mathrm{ao}}\right) * \mathrm{Lch}=\mathrm{C}_{\mathrm{Lch}} *\left(\rho_{\mathrm{ao}} * \mathrm{~V}^{2} / 2\right)+\left(0.5 * \rho_{\mathrm{ao}} * \mathrm{C}_{\text {tray }} * \mathrm{~V}^{2}\right)^{* 4} \\
\mathrm{~m}_{\mathrm{a}}=\mathrm{A}_{\mathrm{cs}} *(2 * \mathrm{~g} * \mathrm{Lch} / \mathrm{C})^{0.5} *\left(\left(\rho_{\mathrm{amb}}-\rho_{\mathrm{ao}}\right) / \rho_{\mathrm{ao}}\right)^{0.5} \\
\mathrm{C}=\mathrm{C}_{\mathrm{Lch}}+\mathrm{C}_{\text {tray }}+\mathrm{C}_{\mathrm{Lc}}=\mathrm{f} * \mathrm{Lch} / \mathrm{Dhch}+4 * \mathrm{C}_{\text {tray }}+\mathrm{f} * \mathrm{Lc} / \mathrm{Dhc}
\end{array}
$$

Where the loss coefficient for the tray $\left(C_{\text {tray }}\right)$ is assumed to be 2 and friction factor $(f)$ for laminar flow $(\mathrm{ReDh}<2300)$ is assumed to be 0.02 .

$$
\begin{aligned}
& \text { Dhch }=2 * \mathrm{~W} * \mathrm{l} /(\mathrm{W}+1) \\
& \text { Dhc }=2 * \mathrm{a} * \mathrm{~b} /(\mathrm{a}+\mathrm{b})
\end{aligned}
$$

As illustrated previously, formulas used to calculate the fluid physical properties at any temperature are given by empiric correlations fitted using air tables. The equations are:

$$
\begin{array}{r}
\rho_{\mathrm{ao}}=360.77819 *\left(\mathrm{~T}_{\mathrm{ao}}+273\right)^{-1.00336} \\
\rho_{\mathrm{amb}}=360.77819 *\left(\mathrm{~T}_{\mathrm{amb}}+273\right)^{-1.00336} \\
\mu_{\mathrm{ao}}=3.3 * 10^{-7} *\left(\mathrm{~T}_{\mathrm{ao}}+273\right)^{0.7}
\end{array}
$$

\section{Results and Discussion}

\section{a. Solar Irradiation}

Equations 1-16 were solved using EES software. It appears that the maximum solar irradiation on the collector equals $1025 \mathrm{~W} / \mathrm{m}^{2}$ and for the vertical wall of the chamber $405 \mathrm{~W} / \mathrm{m}^{2}$ at $1 \mathrm{p} . \mathrm{m}$. Table 1 shows the results for solar irradiation and ambient temperature calculated previously. It is clear that as the solar irradiation increases the outlet temperature from the collector increases. Hence, the temperature difference between the outlet air from the collector and the ambient temperature increases, and so the densities, resulting in increasing the buoyancy force and the mass flow rate of the air. Moreover, as the length of the solar collector increases the time at which the air is heated increases as shown in table 2 . Hence, the air will be heated to a higher temperature, increasing the density difference. 
Table 1. Solar irradiation and ambient temperature in Jordan for horizontal and vertical surfaces.

\begin{tabular}{ccccccccc}
\hline $\begin{array}{c}\text { Time } \\
(\mathrm{hrs})\end{array}$ & $\begin{array}{c}\text { Ambient } \\
\text { temperature }\left({ }^{\circ} \mathrm{C}\right)\end{array}$ & $\begin{array}{c}\text { Direct } \\
\text { radiation on } \\
\text { the collector } \\
\left(\mathrm{W} / \mathrm{m}^{2}\right)\end{array}$ & $\begin{array}{c}\text { Direct } \\
\text { radiation on } \\
\text { the chamber } \\
\left(\mathrm{W} / \mathrm{m}^{2}\right)\end{array}$ & $\begin{array}{c}\text { Diffuse } \\
\text { radiation on } \\
\text { the collector } \\
\left(\mathrm{W} / \mathrm{m}^{2}\right)\end{array}$ & $\begin{array}{c}\text { Diffuse } \\
\text { radiation on } \\
\text { the chamber } \\
\left(\mathrm{W} / \mathrm{m}^{2}\right)\end{array}$ & $\begin{array}{c}\text { Reflected } \\
\text { radiation on } \\
\text { the chamber } \\
\left(\mathrm{W} / \mathrm{m}^{2}\right)\end{array}$ & $\begin{array}{c}\text { Total } \\
\text { radiation on } \\
\text { the collector } \\
\left(\mathrm{W} / \mathrm{m}^{2}\right)\end{array}$ & $\begin{array}{c}\text { Total } \\
\text { radiation on } \\
\text { the chamber } \\
\left(\mathrm{W} / \mathrm{m}^{2}\right)\end{array}$ \\
\hline 8 & 20.532 & 287.0619 & 0.0 & 92.65098 & 16.92495 & 62.65262 & 379.7128 & 79.57757 \\
9 & 21.858 & 486.7992 & 0.0 & 106.6862 & 28.45661 & 97.92509 & 593.4854 & 126.3817 \\
10 & 23.388 & 661.4286 & 40.42868 & 113.7619 & 39.94283 & 127.9064 & 775.1905 & 208.2779 \\
11 & 25.122 & 795.6015 & 109.936 & 117.5748 & 49.74723 & 150.6741 & 913.1763 & 310.3574 \\
12 & 26.754 & 878.911 & 159.0214 & 119.4847 & 56.27654 & 164.7353 & 998.3957 & 380.0332 \\
1 & 27.978 & 905.172 & 177.9454 & 120.0296 & 58.40569 & 169.1583 & 1025.202 & 405.5093 \\
2 & 28.794 & 872.4636 & 163.6277 & 119.347 & 55.75902 & 163.6487 & 991.8106 & 383.0355 \\
3 & 29.1 & 783.1801 & 117.1008 & 117.2636 & 48.80289 & 148.5732 & 900.4437 & 314.4769 \\
4 & 28.794 & 643.9699 & 42.81773 & 113.1809 & 38.73065 & 124.9299 & 757.1508 & 206.4783 \\
5 & 28.08 & 465.718 & 0.0 & 105.5921 & 27.16332 & 94.26616 & 571.3101 & 121.4295 \\
6 & 26.958 & 264.4845 & 0.0 & 90.318 & 15.71061 & 58.54242 & 354.8025 & 74.25303 \\
\hline
\end{tabular}

Table 4. Data considering the experimental solar collector.

\begin{tabular}{cccccc}
\hline Time (hrs) & $\begin{array}{c}\text { Ambient temperature } \\
\left({ }^{\circ} \mathrm{C}\right)\end{array}$ & Outlet temperature $\left({ }^{\circ} \mathrm{C}\right)$ & $\begin{array}{c}\text { Air mass flow } \\
\text { rate }(\mathrm{kg} / \mathrm{s})\end{array}$ & $\begin{array}{c}\text { Temperature difference } \\
\left({ }^{\circ} \mathrm{C}\right)\end{array}$ & $\begin{array}{c}\text { Solar collector } \\
\text { efficiency } \%\end{array}$ \\
\hline 9 & 21.86 & 30.53 & 0.02482 & 8.668 & 37.95 \\
10 & 23.39 & 33.74 & 0.02677 & 10.35 & 37.43 \\
11 & 25.12 & 36.66 & 0.02792 & 11.54 & 36.94 \\
12 & 26.75 & 39 & 0.02847 & 12.25 & 36.57 \\
1 & 27.98 & 40.46 & 0.02854 & 12.48 & 36.37 \\
2 & 28.79 & 41.02 & 0.02817 & 12.23 & 36.53 \\
3 & 29.1 & 40.6 & 0.02733 & 11.5 & 36.36 \\
5 & 28.79 & 39.06 & 0.02597 & 10.27 & 3.518 \\
\hline
\end{tabular}

Also the effect of changing the width of the collector on the outlet temperature and mass flow rate of the air is studied at different solar radiations as shown in table 3. Obviously table 3 shows that the temperature of the air slightly decreases while the mass flow rate of the air increase as the width of the collector increases. It is of various importance to achieve high air temperatures in drying systems in order to enhance the evaporation of water from the product. Moreover, increasing the mass flow rate of the air will enhance the mass transfer process of water from the product to the drying air. Figure 4 shows the relation between temperature difference of the ambient and the output of the solar collector versus the mass flow rate of the air. According to the solar collector considered in this study, data for the outlet air temperature, efficiency and mass flow rate of the air are given in table 4.

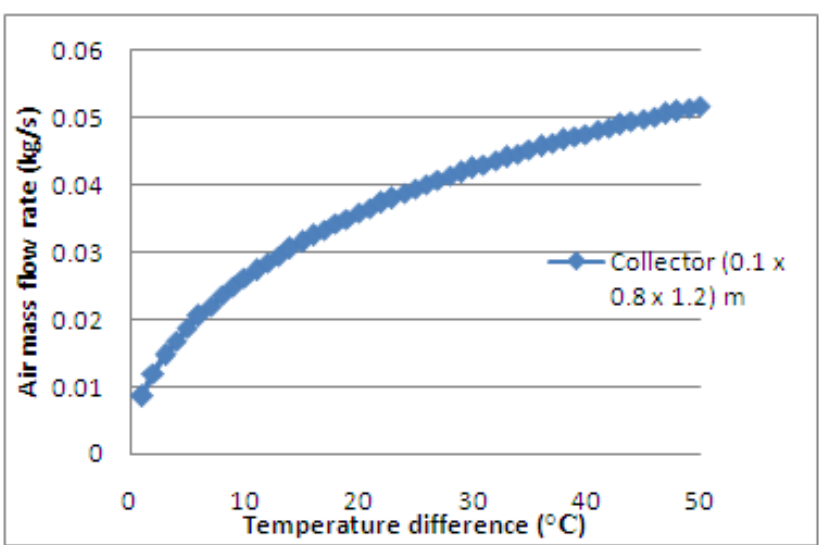

Figure 4. Mass flow rate of the air as function of temperature difference. 


\section{b. Drying chamber results}

Theoretically, the temperatures at each point shown in figure 5 were calculated, in addition to the humidity ratio in each zone, using equations illustrated for the drying chamber. Figure 6 shows the results for these temperatures. Figure 7 shows the results of the humidity ratio in each zone at each time of the day.

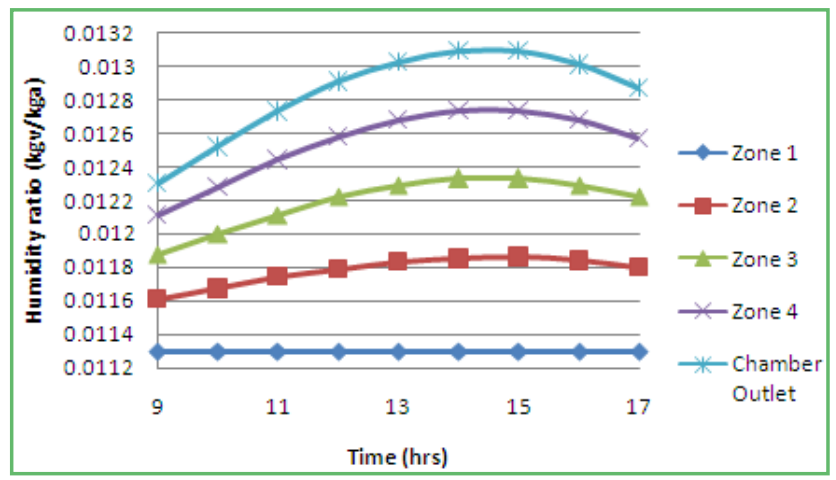

Figure 6. Temperatures at each point in chamber.

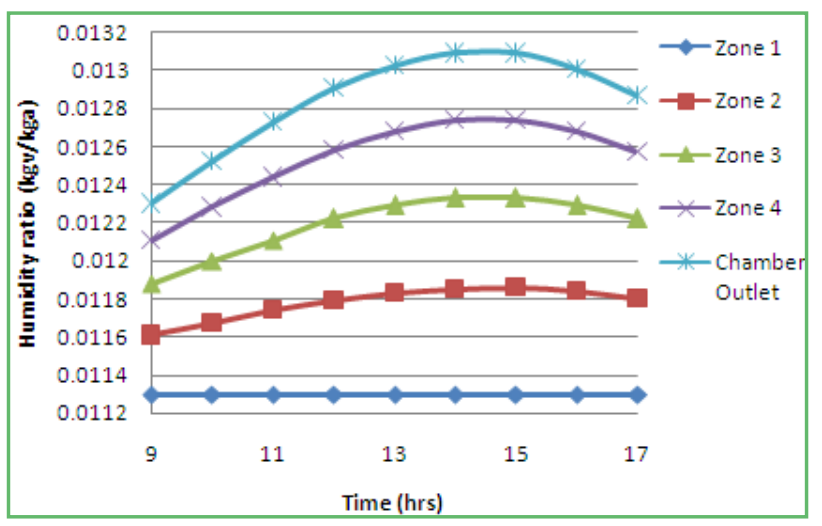

Figure 7. Humidity ratios in each zone.

The mass flow rate of the evaporated water from the product differs at each time of the day depending on the mass flow rate of the air, air velocity, mass of product to be dried, initial and final moisture content and drying air temperature.
Results for drying rates at each hour of the day are shown in table 5. In table 5 the drying rate for each tray increases until $2 \mathrm{pm}$, after that the drying rate starts to decrease since the effect of the sun will start to diminish.

Time needed for products to dry completely, that is, reaching a final moisture content of $10 \%$ of its original mass, is a bit confusing; since the solution is based on steady state assumption, the drying time will be estimated considering that the product is subjected to the same solar radiation at all time and the temperatures at each point and humidity ratio at each zone are constant. Hence, giving an approximated time based on the average time at different solar radiations would give a good approximation. The drying time for each tray was sketched versus the time during the day (different solar radiations) based on table 6 as shown in figure 8 .

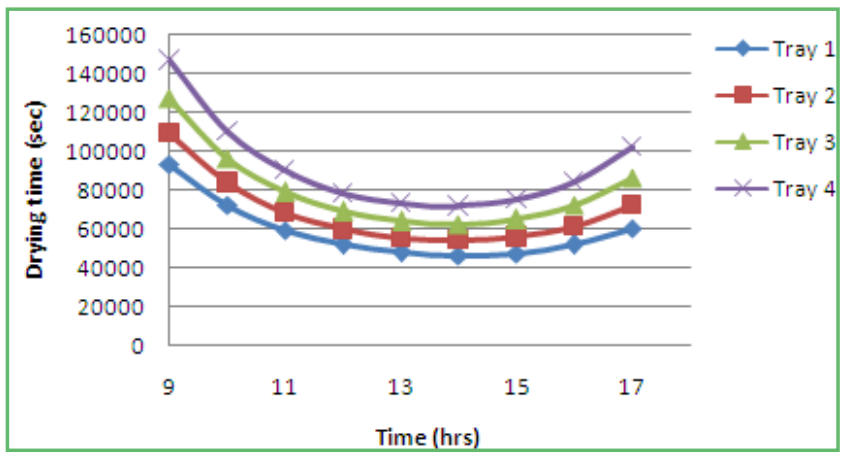

Figure 8. Drying times for each tray at different solar radiations through out the day

According to the data determined in table 6, an approximated drying time for each tray having a mass of $1 \mathrm{~kg}$ and 20 particles of Jameed that need to be dried from $75 \%$ moisture content (wet basis) to $10 \%$ moisture content (wet basis) is shown in table 7 .

Table 7. Drying time for each tray for a capacity of $1 \mathrm{~kg}$.

\begin{tabular}{ccccc}
\hline & Tray 1 & Tray 2 & Tray 3 & Tray 4 \\
\hline $\begin{array}{c}\text { Drying time } \\
\text { (hrs) }\end{array}$ & 16.4 & 19.14 & 22.26 & 25.71 \\
\hline
\end{tabular}

Table 5. Drying rates for each hour

\begin{tabular}{cccccc}
\hline $\begin{array}{c}\text { Time } \\
(\mathrm{hrs})\end{array}$ & $\begin{array}{c}\text { Drying rate for tray 1 } \\
(\mathrm{kg} / \mathrm{s})\end{array}$ & $\begin{array}{c}\text { Drying rate for tray } 2 \\
(\mathrm{~kg} / \mathrm{s})\end{array}$ & $\begin{array}{c}\text { Drying rate for tray 3 } \\
(\mathrm{kg} / \mathrm{s})\end{array}$ & $\begin{array}{c}\text { Drying rate for tray } 4 \\
(\mathrm{~kg} / \mathrm{s})\end{array}$ & $\begin{array}{c}\text { Mass flow rate } \\
\text { of the air }(\mathrm{kg} / \mathrm{s})\end{array}$ \\
\hline 9 & 0.000007741 & 0.000006611 & 0.000005682 & 0.000004911 & 0.02482 \\
10 & 0.00001001 & 0.000008628 & 0.000007485 & 0.000006533 & 0.02677 \\
11 & 0.00001218 & 0.00001053 & 0.000009159 & 0.000008019 & 0.02792 \\
12 & 0.00001398 & 0.00001208 & 0.00001051 & 0.000009195 & 0.02847 \\
1 & 0.00001513 & 0.00001304 & 0.00001131 & 0.00000988 & 0.02854 \\
2 & 0.00001556 & 0.00001335 & 0.00001154 & 0.00001003 & 0.02817 \\
3 & 0.00001519 & 0.00001295 & 0.00001112 & 0.000009608 & 0.02733 \\
4 & 0.00001394 & 0.00001177 & 0.00001001 & 0.000008573 & 0.02597 \\
5 & 0.00001202 & 0.000009986 & 0.0000008364 & 0.000007056 & 0.02387 \\
\hline
\end{tabular}


Table 6. Drying time for each tray.

\begin{tabular}{ccccccc}
\hline $\begin{array}{c}\text { Time } \\
(\mathrm{hrs})\end{array}$ & $\begin{array}{c}\text { Total solar radiation on } \\
\text { collector }\left(\mathrm{W} / \mathrm{m}^{2}\right)\end{array}$ & $\begin{array}{c}\text { Total solar radiation } \\
\text { on chamber } \\
\left(\mathrm{W} / \mathrm{m}^{2}\right)\end{array}$ & $\begin{array}{c}\text { Drying time for } \\
\text { tray 1 (sec) }\end{array}$ & $\begin{array}{c}\text { Drying time for } \\
\text { tray 2 (sec) }\end{array}$ & $\begin{array}{c}\text { Drying time for } \\
\text { tray 3 (sec) }\end{array}$ & $\begin{array}{c}\text { Drying time for } \\
\text { tray } 4(\mathrm{sec})\end{array}$ \\
\hline 9 & 593.5 & 117.9 & 93299 & 109240 & 127117 & 147050 \\
10 & 775.2 & 243.1 & 72164 & 83706 & 96486 & 710543 \\
11 & 913.2 & 344 & 59316 & 68610 & 78851 & 90058 \\
12 & 998.4 & 408.2 & 51661 & 59792 & 68749 & 78544 \\
1 & 1025 & 428.6 & 47739 & 55394 & 63843 & 73102 \\
2 & 991.8 & 403.2 & 46408 & 54090 & 62609 & 71986 \\
4 & 900.4 & 334.6 & 47532 & 55770 & 64970 & 75171 \\
5 & 757.2 & 230.2 & 51802 & 61360 & 72148 & 86351 \\
\hline
\end{tabular}

\section{Conclusion}

The mathematical modeling for a simple solar dryer was constructed, explained and solved using engineering equation solver software (EES). The solar dryer was used to dry Jameed. It is also applicable to dry any type of food product that is acceptable to be dried in direct contact methods (food with low concentration of fat), since the steady state drying process is very dependent on the film of moisture on the surface of the food. Thus knowing the initial mass of the food, its initial moisture content and desired moisture content will be enough to give an acceptable approximation of the drying time needed for the food.

The solar drying system can be optimized to calculate the dimensions of the solar collector to give a higher value of air temperature and flow rate. It is clear that the temperature and air flow rate increases as the length of the absorber increases. Moreover, the width of the collector is inversely proportional to the outlet temperature and directly proportional to air flow rate. In choosing the optimized dimensions one should remember the cost of the system that increases as the material's quantity used increases. Choosing the collector dimensions to be $0.1 \mathrm{~m} \times 0.4 \mathrm{~m} \times 3.0 \mathrm{~m}$ (height, width and length) would give a good optimization regarding the mass flow rate and temperature of the air in addition to the price of the system, but it is not the perfect optimization. To evaluate the perfect optimization one should make use of the optimization techniques such as: Lagrange method, golden section method...etc, to optimize the system for any objective desired. System efficiency can be enhanced in many ways. Flat plate solar collector can be tilted to achieve a highest solar irradiation absorbed. Hundreds of solar collector designs were made, having a higher efficiency than that of the flat plate collector. Materials that are used for insulation can be used to achieve higher resistance of heat transfer. Multi-pass collectors used to achieve higher air flow rate with higher temperature. Drying chamber design can also be modified to enhance the efficiency of the drying system, starting by coating the walls with black paint for higher solar radiation absorption or insulate them for less heat losses to the ambient. Transforming the system from natural convection to forced convection will have a high effect on the drying rate of the products, thus improving the overall performance of the system. This can be done by adding a blower at the inlet of the collector. Blowers are a low demanding power devices thus consumes a small amount of electricity; this will make the system somehow more desirable. 
Nomenclature

Units

\begin{tabular}{|c|c|c|}
\hline $\mathrm{a}$ & Solar collector height & $\mathrm{m}$ \\
\hline A & Apparent solar irradiation at air mass equal to zero & $\mathrm{W} / \mathrm{m}^{2}$ \\
\hline Acs & Cross sectional area of the solar collector & $\mathrm{m}^{2}$ \\
\hline Af & Surface area of the food particle & $\mathrm{m}^{2}$ \\
\hline b & Solar collector width & $\mathrm{m}$ \\
\hline B & Atmospheric extinction coefficient & ---- \\
\hline c & Ratio of diffuse irradiation on a horizontal surface to direct normal irradiation & --- \\
\hline $\mathrm{C}$ & Loss coefficient & ---- \\
\hline Сра & Specific heat of the air & $\mathrm{J} / \mathrm{kg} \cdot \mathrm{k}$ \\
\hline $\mathrm{D}$ & Diameter of food particle & $\mathrm{m}$ \\
\hline $\mathrm{Dh}$ & Hydraulic diameter & $\mathrm{m}$ \\
\hline Dhc & Hydraulic diameter of the collector & $\mathrm{m}$ \\
\hline Dhch & Hydraulic diameter of the chamber & $\mathrm{m}$ \\
\hline diff & Diffusivity of air & ---- \\
\hline DT & Drying time & $\mathrm{s}$ \\
\hline EOT & Equation of time & $\min$ \\
\hline $\mathrm{f}$ & Friction factor & ---- \\
\hline Fwg & Configuration factor of vertical surface & ---- \\
\hline $\mathrm{g}$ & Gravity acceleration & $\mathrm{m} / \mathrm{s}^{2}$ \\
\hline G & Solar irradiation & $\mathrm{W} / \mathrm{m}^{2}$ \\
\hline $\mathrm{h}$ & Hour angle & deg \\
\hline hf & Convection heat transfer coefficient between the air and the surface of the food at different trays & $\mathrm{W} / \mathrm{m}^{2} \cdot \mathrm{k}$ \\
\hline hfg & Latent heat of vaporization for water in the food at different trays & $\mathrm{J} / \mathrm{kg}$ \\
\hline hi & Convection heat transfer coefficient inside the solar collector & $\mathrm{W} / \mathrm{m}^{2} \cdot \mathrm{k}$ \\
\hline ho & Convection heat transfer coefficient of ambient wind & $\mathrm{W} / \mathrm{m}^{2} \cdot \mathrm{k}$ \\
\hline $\mathrm{k}$ & Thermal conductivity & $\mathrm{W} / \mathrm{m} \cdot \mathrm{k}$ \\
\hline $\mathrm{kg}$ & Mass transfer coefficient & $\mathrm{Kg} / \mathrm{m}^{2} . \mathrm{s}$ \\
\hline 1 & depth of the drying chamber & $\mathrm{m}$ \\
\hline $\mathrm{L}$ & Latitude angle & $\operatorname{deg}$ \\
\hline $\mathrm{Lc}$ & Length of the solar collector & $\mathrm{m}$ \\
\hline Lch & Length of the drying chamber & $\mathrm{m}$ \\
\hline LCT & Local civil time & hrs \\
\hline LST & Local solar time & hrs \\
\hline $\mathrm{m}$ & Mass flow rate & $\mathrm{Kg} / \mathrm{s}$ \\
\hline M & Mass & $\mathrm{Kg}$ \\
\hline ma & Mass flow rate of the air & $\mathrm{Kg} / \mathrm{s}$ \\
\hline $\mathrm{N}$ & Number of food particles on each tray & Particle \\
\hline$P$ & Pressure & $\mathrm{Pa}$ \\
\hline Q & Heat transfer & W \\
\hline ref & Reflectivity of the ground & ---- \\
\hline $\mathrm{s}$ & Distance between trays & $\mathrm{m}$ \\
\hline $\mathrm{t}$ & Thickness & $\mathrm{m}$ \\
\hline $\mathrm{T}$ & Temperature & ${ }^{\circ} \mathrm{C}$ \\
\hline $\mathrm{V}$ & Velocity & $\mathrm{m} / \mathrm{s}$ \\
\hline $\mathrm{w}$ & Humidity ratio & $(\mathrm{Kg})_{\text {water }} /(\mathrm{kg})_{\text {air }}$ \\
\hline W & Width of the drying chamber & $\mathrm{m}$ \\
\hline $\mathrm{X}$ & Percentage of daily range & $\%$ \\
\hline $\mathrm{zf}$ & Final moisture content wet basis & $\%$ \\
\hline zi & Initial moisture content wet basis & $\%$ \\
\hline
\end{tabular}

\section{Greek symbols}

\begin{tabular}{lll}
\hline$\alpha$ & Absorptivity & --- \\
$\beta$ & Expansion coefficient & $\mathrm{K}^{-1}$ \\
$\mathrm{Y}$ & Solar surface azimuth & $\mathrm{deg}$ \\
$\delta$ & Sun's declination & $\mathrm{deg}$ \\
$\varepsilon$ & Emissivity & --- \\
$\theta$ & Angle of incidence & $\mathrm{deg}$ \\
$\lambda$ & Solar altitude angle & $\mathrm{deg}$ \\
$\mu$ & Dynamic viscosity & $\mathrm{N} . \mathrm{s} / \mathrm{m}^{2}$ \\
$\nu$ & Kinematic viscosity & $\mathrm{m}^{2} / \mathrm{s}$ \\
$\xi$ & Tilt angle & $\mathrm{deg}$ \\
$\rho$ & Density & $\mathrm{Kg} / \mathrm{m}^{3}$ \\
$\sigma$ & Steven Boltzmann constant & $\mathrm{W} / \mathrm{m}^{2} \cdot \mathrm{k}^{4}$ \\
$\tau$ & Transmissivity & --- \\
$\psi$ & Solar azimuth angle & $\mathrm{deg}$ \\
\hline
\end{tabular}




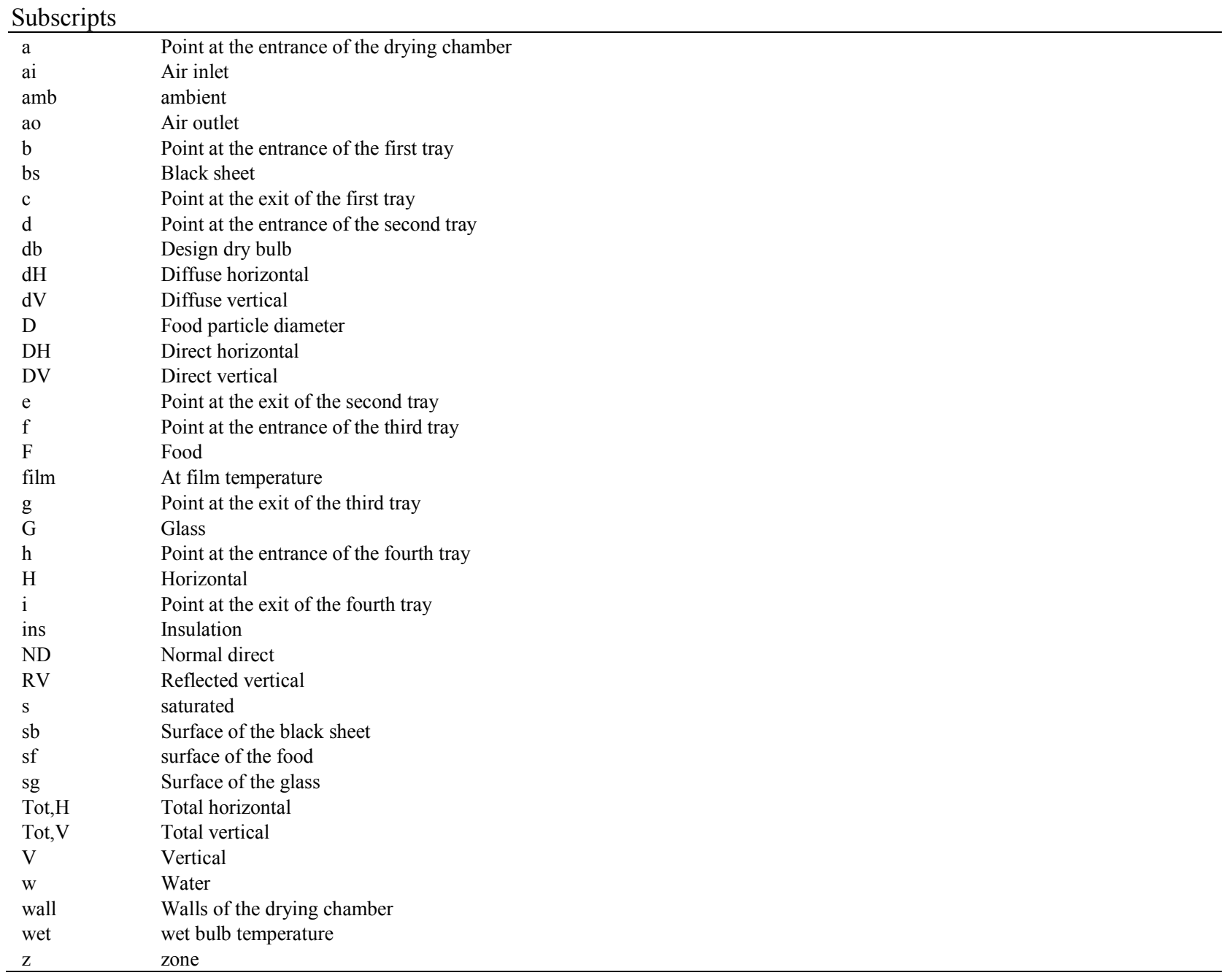

\section{REFERENCES}

[2] Christie John Geankoplis, Transport Processes and Separation Process Principles, 4th ed. New Jersey: Prentice Hall, 2008.

[3] Othieno H., "Circulation of Air in Natural-Convection Solar Dryers: research and development solar drying in Africa", In Proceedings of a Workshop held in Dakar; 1986. p. 47-59.

[4] Amouzou K., Gnininvani M. and Kerim B., "Solar Drying Problem in Togo: research and development solar drying in Africa", In Proceedings of a Workshop held in Dakar; 1986. p. 252-71.

[5] Bolaji BO., "Development and Performance Evaluation of Box-Type Absorber Solar Air Collector for Crop Drying", Journal of Food Technology 2005; 3(4): 515-600.

[6] Bolaji BO, Olalusi AP., "Performance Evaluation of a Mixed-Mode Solar Dryer", AU Journal of Technology 2008; 11(4):225-31.

[7] Simate IN., "Optimization of mixed-mode and indirect-mode natural convection solar dryers", Renewable Energy 2003; 28:435-53.

[8] Madhlopa A, Jones SA and Saka JDK, “A Solar Air Heater with Composite-Absorber Systems for Food Dehydration", Renewable Energy 2002; 27:27-37.

[9] Ekechukwe OV, Norton B., "Review of Solar Energy Drying Systems II: an overview of solar drying technology", Energy Conversion and Management 1999; 40:616-55.

[10] Frank P. Incropera, David P. DeWitt, Theodore L. Bergman and Adrienne S. Lavine, Fundamentals of Heat and Mass transfer, 6th ed. New York: Wiley and Sons Book Company, 2007.

[11] Faye C. McQuiston, Jerald D. Parker and Jefferey D. Spitler, Heating, Ventilation and Air Conditioning, 6th ed. New York: Wiley and Sons Book Company, 2003.

[12] Christie John Geankoplis, Transport Processes and Separation Process Principles, 4th ed. New Jersey: Prentice Hall, 2008.

[13] R.L. Earle, M.D. Earle, Unit operations in food processing, 2nd edition. New Zealand: The New Zealand Institute of Food Science and Technology (Inc.), 1983. 